\title{
Bioreduction and Bioremoval of Hexavalent Chromium by Genetically Engineered Strains (Escherichia Coli MT2A and Escherichia Coli MT3)
}

\section{Şeyma Akkurt}

Adıyaman Üniversitesi: Adiyaman Universitesi

\section{Merve Oğuz}

Erciyes Üniversitesi: Erciyes Universitesi

Aysel Alkan Uçkun ( $\sim$ auckun@adiyaman.edu.tr )

Adıyaman Üniversitesi: Adiyaman Universitesi https://orcid.org/0000-0002-8957-7476

\section{Research Article}

Keywords: $\mathrm{Cr}(\mathrm{VI})$ bioreduction, chromium removal, genetical engineered bacteria, bioremediation, metalloproteins, biological treatment.

Posted Date: August 20th, 2021

DOI: https://doi.org/10.21203/rs.3.rs-710686/v1

License: (c) (i) This work is licensed under a Creative Commons Attribution 4.0 International License. Read Full License

Version of Record: A version of this preprint was published at World Journal of Microbiology and Biotechnology on January 25th, 2022. See the published version at https://doi.org/10.1007/s11274-022-03235-2. 


\section{Abstract}

Studies on the removal of toxic metals from water by genetic engineering applications are becoming more and more diverse. Especially by the expression of cysteine and thiol rich proteins such as metallothioneins in bacterial cells, a high rate of removal of metal ions from the environment is ensured. In this study, we evaluated the removal and reduction of hexavalent chromium $\mathrm{Cr}(\mathrm{VI})$ from aqueous solutions with the recombinant strains obtained by cloning the human metallothioneinsMT2A and MT3 into Escherichia coli Jm109.E. coli MT2A was the most effective strain in both $\mathrm{Cr}(\mathrm{VI})$ removal (89\%in $25 \mathrm{mg} / \mathrm{L} \mathrm{Cr}(\mathrm{VI})$ application) and $\mathrm{Cr}(\mathrm{VI})$ reduction (76\%in $25 \mathrm{mg} / \mathrm{L} \mathrm{Cr}(\mathrm{VI})$ application). $\mathrm{Cr}(\mathrm{VI})$ adsorbed per dry cell (at $25 \mathrm{mg} / \mathrm{L}$ ) were $17 \mathrm{mg} / \mathrm{g}, 22 \mathrm{mg} / \mathrm{g}$ and $19 \mathrm{mg} / \mathrm{g}$ for Jm109, MT2A and MT3, respectively. Scanning electron microscope (SEM) images showed that the morphological structures of $\mathrm{Cr}(\mathrm{VI})$ treated cells were significantly damaged compared to control cells. Scanning transmission electron microscope (STEM) images showed black spots in the cytoplasm of cells treated with $\mathrm{Cr}(\mathrm{VI})$.From the shifts in the Fourier transform infrared spectroscopy analysis (FTIR) spectra of the cells treated with $\mathrm{Cr}(\mathrm{VI})$ compared to the control cells, it was determined that the groups interacting with $\mathrm{Cr}$ were amino, hydroxyl, methyl and sulfhydryl. When all these experimental data were evaluated together, it was concluded that all three species were effective in removing $\mathrm{Cr}(\mathrm{VI})$ from aqueous solutions and MT2A strain could be used as the most effective biotechnological tool.

\section{Introduction}

Chromium ( $\mathrm{Cr}$ ) is one of the important pollutants in nature that has high toxicity even at low doses (Kushwaha et al. 2018). $\mathrm{Cr}$ is usually found in two forms, trivalent $\mathrm{Cr}(\mathrm{III})$ and hexavalent $\mathrm{Cr}(\mathrm{VI}) . \mathrm{Cr}(\mathrm{III})$ is beneficial to human health at specific level due to its participation in lipid and glucose metabolism (Pradhan et al. 2017). In contrast, $\mathrm{Cr}(\mathrm{VI})$ is a known mutagenic and carcinogenic component for both humans and all living organisms due to its strong oxidizing properties (Fernández et al. 2010). $\mathrm{Cr}(\mathrm{VI})$ is widespread used in industrial applications due to its high resistance to corrosion and hardness (Lu et al. 2013). It is commonly used in many industries, such as electroplating, metallurgy, tanning of leather, wood defense, production of stainless steel, paint, pigment and production of pulp (Dhal et al. 2013; Jobby et al. 2018). In these industries, wastes containing $\mathrm{Cr}(\mathrm{VI})$ such as sludge, fly ash and slag are produced (Fernández et al. 2018). $\mathrm{Cr}(\mathrm{VI})$ causes many diseases in humans, such as skin rash, kidney and liver damage, internal bleeding, dental abnormalities, respiratory disorders, and lung cancer (Martone et al. 2013). $\mathrm{Cr}(\mathrm{VI})$ is 100 times toxic and 1000 times more mutagenic compared to $\mathrm{Cr}(\mathrm{III})$ (Chang et al. 2019). Reducing $\mathrm{Cr}(\mathrm{VI})$ to $\mathrm{Cr}(\mathrm{III})$ in $\mathrm{Cr}(\mathrm{VI})$ removal is therefore an effective method for significantly reducing the toxic effect of $\mathrm{Cr}(\mathrm{VI})$ (Long et al. 2018; Pan et al. 2014). $\mathrm{Cr}(\mathrm{VI})$ is recognized as one of the priority pollutants by the United States Environmental Protection Agency (USEPA) (USEPA 2014). It has been reported that the discharge limit of wastewater containing $\mathrm{Cr}(\mathrm{VI})$ made by European Union (EU) to surface waters should be below $0.05 \mathrm{mg} / \mathrm{L}$ and that the total concentration of $\mathrm{Cr}$ should be reduced below $2 \mathrm{mg} / \mathrm{L}$ (Chang et al. 2019). The World Health Organization (WHO) has determined the maximum allowable total chromium content in surface water and drinking water to be $0.05 \mathrm{mg} / \mathrm{L}(\mathrm{WHO}$ 2017).

Various physical and chemical methods to remove $\mathrm{Cr}(\mathrm{VI})$ from wastewater (oxidation-reduction process, flocculation, ion exchange, electrochemical methods, membrane filtration and reverse osmosis) are used (Akkoyun et al. 2020; Geva et al. 2016). However these methods have some significant disadvantages, such as high costs, secondary pollution formation, toxic sludge formation, and low treatment efficiency (Ahluwalia and Goyal 2007). To overcome such problems, the bioremediation process is an important alternative (Anusha and Natarajan 2020). Bioremediation is an environmentally friendly, clean, inexpensive and efficient treatment process in which contaminants are removed using microorganisms (Ayangbenro and Babalola 2017). However, wild bacterial strains isolated from contaminated environments do not have the ability to selectively bind metals and have a low ability to remove them (Ayangbenro and Babalola 2017).

On the other hand, today genetic engineering applications enable both selectively removing the metals and increasing the metal binding capacity of microorganisms (Yang et al. 2015). There are many strategies to increase the metal binding 
capacity of microorganisms. Most of these strategies are based on the binding of metals to recombinant strains by providing metal ion binding polypeptides to the bacterial cell wall (Gupta and Singh 2017). Proteins or peptides such as metallothioneins (MT) or poly-histidins, which have high affinity for metal ions, are cloned to the host cell to increase the metal binding capacity (Ike et al. 2007). MTs are proteins with low molecular weight and high cysteine content found in all living organisms. Metal ions are bonded to sulfhydryl groups in MTs (Pinto et al. 2003). Because of the high thiol content of MTs, they helps detoxify heavy metal group I-II, protects cells and organs from the harmful effects of metals, and is considered free radical scavengers (Hussain et al. 1996). There are four distinct isoforms of mammalian MTs (MT1, MT2A, MT3, MT4) (Miles et al. 2000). In many studies on this subject have shown that genetically engineered $E$. coli strains expressing the MT gene increase the removal of various heavy metals ( $\mathrm{Cr}$, zinc $(\mathrm{Zn})$, copper (Cu), nickel (Ni), arsenic (As), etc.) (Deng and Jia 2011; Kim et al. 2005; Ma et al. 2011, 2019; Uçkun et al. 2021). Human metallothionein MT2A protein, which we use for the removal of $\mathrm{Cr}(\mathrm{VI})$ metal in our study, has several functions. MT2A proteins participate in cell processes and chelate the metal ions, clear large reactive oxygen (ROS) molecules and stimulate antioxidant enzymes (Chen et al. 2014; Starska et al. 2015). Another human metalloprotein that is known to bind metals such as $\mathrm{Zn}, \mathrm{Cu}$, cadmium (Cd) (Toriumi et al. 2005), As (Uçkun et al. 2021) is MT3. In the literature, there is no study related to the $\mathrm{Cr}$ removal of MT2A and MT3 genes from water. The aim of this study was to ensure the removal and reduction of $\mathrm{Cr}(\mathrm{VI})$ from water using genetic engineering technology. For this purpose, the human MT genes (MT2A and MT3) were cloned into host $E$. coli Jm109 and the ability of these cells binding to $\mathrm{Cr}$ was investigated. $\mathrm{Cr}(\mathrm{VI})$ removal and reduction activities of Jm109 strain and other recombinant strains were compared.

\section{Materials And Methods Cultivation Of Strains}

E. coli Jm109 was used as the control strain in our study. Cells were grown in Luria Bertani (LB) medium containing beef extract $(10 \mathrm{~g} / \mathrm{L})$, peptone extract $(10 \mathrm{~g} / \mathrm{L})$ and $\mathrm{NaCl}(3 \mathrm{~g} / \mathrm{L})$ at $37^{\circ} \mathrm{C}$ with $150 \mathrm{rpm}$ shaking. Recombinant cells (MT2A and MT3) were seeded in LB medium containing ampicillin (Merc), unlike the control Jm109 cell.

\section{Preparation Of $\mathrm{Cr}(\mathrm{Vi})$ Solution}

Chemicals used in the preparation of solutions for stock metals were obtained from Merc. In this study, $\mathrm{Cr}(\mathrm{VI})$ stock solution was prepared by dissolving potassium dichromate $\left(\mathrm{K}_{2} \mathrm{Cr}_{2} \mathrm{O}_{7}\right)$ metal salt in distilled water. Then, the $\mathrm{Cr}(\mathrm{VI})$ solution was sterilized in autoclaves and stored at $+4{ }^{0} \mathrm{C}$.

\section{Gene Synthesis, Cloning And Bacterial Transformation}

The human MTs (MT2A and MT3) gene sequences were provided from Twist Bioscience. MT2A and MT3 gene fragments and the pET21 plasmid were double digested with EcoRI and Notl restriction enzymes (Thermo Scientific). Then these genes were individually ligated to the pET21 plasmid. Host Jm109 strain (ATCC 53323) was made competent according to the chemical $\mathrm{CaCl}_{2}$ protocol (Merc). Recombinant pET21 plasmids (Sigma-Aldrich) were transformed into competent Jm109 cells. Then, recombinant (MT2A and MT3) strains were seeded on LB agar plates supplemented with ampicillin (50 $\mu \mathrm{g} / \mathrm{ml}$ ), X-gal (for blue/white cell screening) and IPTG and incubated at $37^{\circ} \mathrm{C}$ overnight. The plasmid was isolated using the QIAGEN Qiaprep Spin Miniprep Kit (Cat no: 27104), and the presence of the positive transformant was confirmed using PCR. To validate additional genes, sequencing libraries of isolated plasmids were prepared and sequenced using Miseq platform (Table 1). 
Table 1

Sequencing libraries for the isolated plasmids

\begin{tabular}{|llllllllll|}
\hline Name & Tube ID & $\begin{array}{l}\text { Insert } \\
\text { Length }\end{array}$ & $\begin{array}{l}\text { Construct } \\
\text { Length }\end{array}$ & $\begin{array}{l}\text { Insert } \\
\text { Sequence }\end{array}$ & $\begin{array}{l}\text { Construct } \\
\text { Sequence }\end{array}$ & $\begin{array}{l}\text { Yield } \\
\text { (ng) }\end{array}$ & NGS & Yield & $\begin{array}{l}\text { Expression } \\
\text { Vector }\end{array}$ \\
\hline MT3 & tSHPs0903B & 300 & 5646 & ATGGACCCT & ATGGACCCT & 612 & PASS & PASS & pET-21 \\
\hline MT2 & tSHPs0903B & 300 & 5646 & ATGGATCCC & ATGGATCCC & 523 & PASS & PASS & pET-21 \\
\hline
\end{tabular}

\section{Minimal Inhibitory Concentration (Mic) Of Cells Against $\mathrm{Cr}(\mathrm{Vi})$}

The $\mathrm{Cr}(\mathrm{VI})$ heavy metal ion resistance capacities of Jm109 and its recombinant strains (MT2A and MT3) were determined by the minimum inhibition concentration. Minimum inhibition concentration experiments were performed with a few minor changes in the method applied by Anusha and Natarajan (2020). Three independent control groups (just LB, LB and metal solution and LB and cell culture) were used in the analysis. Cells were incubated in LB medium containing different concentrations of $\mathrm{Cr}(\mathrm{VI})(0-1000 \mathrm{mg} / \mathrm{L})$ at $37^{\circ} \mathrm{C}$ for 96 hours with shaking to determine the $\mathrm{Cr}(\mathrm{VI}) \mathrm{MIC}$ concentration. Culture samples were taken from the medium at regular time intervals (every 8 hours) and measured at $600 \mathrm{~nm}$ in the microplate reader (Thermo Flash 2000).

\section{Residue of $\mathrm{Cr}$ in the medium and bioreduction of $\mathrm{Cr}(\mathrm{VI})$}

In the bioaccumulation experiments, the method of Shamim et al. (2014) was modified and used. The strains were incubated at $37^{\circ} \mathrm{C}$ and $150 \mathrm{rpm}$ for 24 hours in LB broth containing $\mathrm{Cr}(\mathrm{VI})(0.05-25 \mathrm{mg} / \mathrm{L})$. Samples were taken after the incubation was completed to determine the amount of $\mathrm{Cr}$ remaining in the medium. The samples were centrifuged and the supernatant was filtered with a syringe filter. Total $\mathrm{Cr}$ accumulations in the samples were measured by inductively coupled plasma mass spectrometry (ICP-MS) (PerkinElmer, USA \& Nexion 350X). The $\mathrm{Cr}(\mathrm{VI})$ concentration of the supernatant was analyzed at $540 \mathrm{~nm}$ by the 1,5-diphenylcarbazide (DPC) method (Kathiravan et al. 2011).

The percent decrease in $\mathrm{Cr}(\mathrm{VI})$ was determined in accordance with the formula below.

$\% \mathrm{Cr}(\mathrm{VI})$ reduction: $((\mathrm{Ci}-\mathrm{Cf}) / \mathrm{Ci}) * 100$

Ci: initial $\mathrm{Cr}(\mathrm{VI})$ concentration $\mathrm{mg} / \mathrm{L}$

Cf: final $\mathrm{Cr}(\mathrm{VI})$ concentration $\mathrm{mg} / \mathrm{L}$

\section{Bioremoval Of Cr Analysis}

In order to determine the accumulation of metal on the cell surface, $1 \mathrm{ml}$ of $50 \mathrm{mM}$ EDTA (Merck) solution was applied to the cells precipitated after centrifugation in the previous step. The samples were centrifuged and the supernatant was taken into another tube for ICP MS analysis. The total amount of $\mathrm{Cr}$ in the filtrates was analyzed in the ICP-MS device. To determine the amount of metal removed by the strains, the formula given below was used (Anusha and Natarajan 2020).

$\%$ of Remove of Cr: ((Ci-Cs)/Ci) * 100

$\mathrm{Cr}$ in supernatant (Cs): Remaining concentration of $\mathrm{Cr}$ after bioaccumulation (mg/L)

Initial $\mathrm{Cr}$ concentration $(\mathrm{Ci})$ : Initial concentration of $\mathrm{Cr}$ added into the medium $(\mathrm{mg} / \mathrm{L})$

\section{Sem, Stem And Edx Analyses}


SEM analysis was conducted to view morphological changes on the surface of $\mathrm{Cr}(\mathrm{VI})$ treated cells. STEM (ZEISS, Germany) was used to determine the metal distribution inside bacteria. MT2A cells were grown in a LB medium treated and untreated $\mathrm{Cr}(\mathrm{VI})(25 \mathrm{mg} / \mathrm{L})$ at $150 \mathrm{rpm}$ at $37^{\circ} \mathrm{C}$ for 24 hours. The cells were then centrifuged at $6000 \mathrm{rpm}$ for 20 minutes at $4^{\circ} \mathrm{C}$, the liquid part was discarded and washed three times with the pellet phosphate buffer (PBS, pH 7.2). Then the pellet was fixed to $2.5 \%$ of glutaraldehyde for $4-6$ hours at $4^{\circ} \mathrm{C}$. Cells were washed with PBS and treated with $1 \%$ osmium tetraoxide for 1-2 hours. After fixation, the cells were washed again with PBS and dehydrated by increasing concentrations of ethanol $(15,30,60,90$ and $100 \% \mathrm{v} / \mathrm{v})$. The fixed samples were critically dried thoroughly and goldplatinum (QUORUM) coated. The images of the samples were taken using SEM and Energy Dispersive X-Ray (EDX) (ZEISS \& EVO LS 10, Germany) devices. By making minor changes in the SEM analysis protocol for STEM analysis, samples of MT2A cells that were $\mathrm{Cr}(\mathrm{VI})$ treated and non $\mathrm{Cr}(\mathrm{VI})$ treated cells were prepared.

\section{Ftir Analysis}

FTIR (Perkin Elmer 400 FT-IR/FT-FIR spectrometer) was performed to detect $\mathrm{Cr}(\mathrm{VI})$ binding functional groups on the MT2A cell surface. $\mathrm{Cr}(\mathrm{VI})(25 \mathrm{mg} / \mathrm{L})$ and $\mathrm{Cr}(\mathrm{VI})$ untreated MT2A cells were incubated for 24 hours. The samples were then centrifuged at $5000 \mathrm{rpm}$ for 20 minutes at $4^{\circ} \mathrm{C}$. The supernatant was discarded and the pellet was lyophilized after washing twice with PBS (Karthik et al. 2017). Samples were analyzed on the FTIR Spectrometer between $400 \mathrm{~cm}^{-1}$ and $4000 \mathrm{~cm}^{-1}$ wavelength.

\section{Results}

\section{Cr Bioremoval And Cr(Vi) Bioreduction Capacity Of The Strains}

MIC values of Jm109, MT2A and MT3 cells were found to be 50 ppm, 140 ppm and 75 ppm, respectively. Cr removal rates of bacterial cells from the medium are shown in Fig. 1. Cr removal rates of Jm109 from media containing $\mathrm{Cr}$ at 0.05, 0.1, $0.3,0.5,10$, and $25 \mathrm{mg} / \mathrm{L}$ concentrations are $90 \%, 90 \%, 85 \%, 80 \%, 70 \%$ and $68 \%$, respectively. These rates were $97 \%, 95 \%$, $94 \%, 92 \%, 90 \%$, and $89 \%$ for the MT2A strain, while $95 \%, 91 \%, 89 \%, 83 \%, 80 \%$, and $76 \%$ for the MT3 strain. While the removal rates were close to each other in the first three $\mathrm{Cr}$ concentrations $(0.5 \mathrm{mg} / \mathrm{L}, 0.1 \mathrm{mg} / \mathrm{L}$, and $0.3 \mathrm{mg} / \mathrm{L})$ in each strain, the removal rates decreased as the concentration increased. $\operatorname{Cr}(\mathrm{VI})$ reduction rates from media containing the same $\mathrm{Cr}$ concentrations are shown in Fig. 2. As with total $\mathrm{Cr}$ removal, $\mathrm{Cr}(\mathrm{VI})$ reduction was close to each other and very high at low $\mathrm{Cr}(\mathrm{VI})$ concentrations (in the range of 92-99\%), while at high $\mathrm{Cr}$ concentrations it was low (range of 50\%-82\%). The amounts of $\mathrm{Cr}$ adsorbed per dry cell from the medium containing the highest Cr concentration ( $25 \mathrm{mg} / \mathrm{L})$ were $17 \mathrm{mg} / \mathrm{g}, 22$ $\mathrm{mg} / \mathrm{g}$, and $19 \mathrm{mg} / \mathrm{g}$ for Jm109, MT2A and MT3, respectively (Table 2).

Table 2

Amount of total $\mathrm{Cr}(25 \mathrm{mg} / \mathrm{L})$ remaining in the medium and cell in aqueous solution

\begin{tabular}{|lllll|}
\hline Strains & $\begin{array}{l}\text { Amount of } \mathrm{Cr} \text { in the } \\
\text { medium } \\
(\mathbf{m g} / \mathrm{L})\end{array}$ & $\begin{array}{l}\text { Amount of } \mathrm{Cr} \text { in } \\
\text { the cell } \\
(\mathbf{m g} / \mathrm{L})\end{array}$ & $\begin{array}{l}\text { Amount of adsorbed Cr per } \\
\text { dry cell } \\
(\mathbf{m g} / \mathbf{g} \text { cell) }\end{array}$ & $\begin{array}{l}\text { Percentage of Cr removal of } \\
\text { cells (\%) }\end{array}$ \\
\hline Jm109 & 17 & 8 & 17 & 68 \\
\hline MT2A & 22 & 3 & 22 & 88 \\
\hline MT3 & 19 & 6 & 19 & 76 \\
\hline
\end{tabular}

The growth tolerance of the MT2A cell against different $\mathrm{Cr}(\mathrm{VI})(0-400 \mathrm{mg} / \mathrm{L})$ concentrations of the MT2A strain is shown in Fig. 3. Cells grew at low $\mathrm{Cr}(\mathrm{VI})$ concentrations, whereas it was inhibited at increasing $\mathrm{Cr}(\mathrm{VI})$ concentrations. When a $\mathrm{Cr}$ concentration of $100 \mathrm{mg} / \mathrm{L}$ and above was applied, growth was significantly reduced. The first inhibition occurred at 100 , 
200, $400 \mathrm{mg} / \mathrm{L} \mathrm{Cr}(\mathrm{VI})$ concentrations between 12 and 18 hours. At the 24th hour, $75 \mathrm{mg} / \mathrm{L} \mathrm{Cr}(\mathrm{VI})$ concentration was added to this concentration range.

\section{Sem And Stem Images Of The Cells}

Since MT2A is the most effective strain in Cr removal, SEM and STEM images of this strain were taken. The appearance of MT2A cells unexposed to $\mathrm{Cr}$ was uniform, without any deformation and bacillus shaped (Fig. 4a). After exposure to Cr, it was observed that the shape of the cells elongated, overlapped and agglomerated, and the surface of some was significantly dispersed (Fig. 4b). Cr accumulation in the cell wall of $\mathrm{Cr}(\mathrm{VI})$ treated cells is confirmed by $\mathrm{Cr}$ peaks in the EDX spectra. While no $\mathrm{Cr}$ peak was observed in the EDX of MT2A control cells, a $\mathrm{Cr}$ peak was observed in $\mathrm{Cr}$ treated cells. STEM images of $25 \mathrm{mg} / \mathrm{L} \mathrm{Cr}(\mathrm{VI})$ treated cells had obvious black spots that could represent intracellular Cr precipitation (Fig. 5). These black spots were absent in control cells that were not treated with $\mathrm{Cr}(\mathrm{VI})$.

\section{Ftir Spectra Of The Cells}

FTIR analysis was performed only for the MT2A strain. Figure 6 shows the FTIR spectra of MT2A bacterial cells treated with $100 \mathrm{mg} / \mathrm{L} \mathrm{Cr}(\mathrm{VI})$ and untreated with $\mathrm{Cr}(\mathrm{VI})$ (control). Increases were observed in the FTIR spectra of the $\mathrm{Cr}(\mathrm{VI}) \operatorname{treated}$ cells compared to the control. These increases are due to the activity of functional groups on the cell surface and suggest that $\mathrm{Cr}(\mathrm{VI})$ binds to the cell membrane. In the $\mathrm{Cr}(\mathrm{VI})$ treated cells, peak $3267 \mathrm{~cm}^{-1}$ indicates strong $\mathrm{OH}$ peak. The presence of $\mathrm{OH}$ peak in the $\mathrm{Cr}(\mathrm{VI})$ treated cell may have been caused by low concentration of $\mathrm{Cr}(\mathrm{III})$ hydroxide precipitation. A similar result to ours was observed by Wu et al. (2019) in the formation of an $\mathrm{OH}$ peak due to chromium oxide deposition after $\mathrm{Cr}(\mathrm{VI})$ application to Bacillus sp. CR7. In this study, the spectrum of $2923.4 \mathrm{~cm}^{-1}$ in control shifted to three separate spectra $\left(2962.8,2917.7,2840.4 \mathrm{~cm}^{-1}\right)$ in the bacterial cells exposed to $\mathrm{Cr}(\mathrm{VI})$. These shifts mean that $\mathrm{Cr}$ binds to the methyl group of the cells. The shift of the $1514.4 \mathrm{~cm}^{-1}$ band in the control cell to the $1531.2 \mathrm{~cm}^{-1}$ band in the $\operatorname{Cr}(\mathrm{VI})$ applied cell, may be due to the interaction between nitrogen groups $(\mathrm{N}-\mathrm{O})$ and $\mathrm{Cr}(\mathrm{VI})$ on the cell surface. The $1379.1 \mathrm{~cm}^{-1}$ peak in the control cell shifted to $1387.1 \mathrm{~cm}^{-1}$ in the $\mathrm{Cr}(\mathrm{VI})$ applied cell. This shift indicates that sulfate groups (S-O) are effective in the absorption of $\mathrm{Cr}(\mathrm{VI})$.

\section{Discussion}

The metal binding capacity of genetically modified microorganisms increases even more than wild strains (Yang et al. 2015). In our study, the strain that removed the most $\mathrm{Cr}$ at each concentration and most effective in reducing $\mathrm{Cr}(\mathrm{VI})$ was MT2A. In the literature, there are many studies on the removal of $\mathrm{Cr}(\mathrm{VI})$ from water. In a study conducted by Zeng et al. (2019), it was found that Oceanobacillus oncorhynchi W4 a newly isolated $\operatorname{Cr}(\mathbb{\nabla})$ reducing bacterium, removed $74.2 \%$ of $\mathrm{Cr}(\mathrm{VI})$ from aqueous solution in $72 \mathrm{~h}$. Bharagava and Mishra (2018) observed that Cellulosimicrobium sp. strain isolated from common effluent treatment plant of tannery industries reduced $\mathrm{Cr}(\mathrm{VI})$ by $99.33 \%$ in $24 \mathrm{~h}$ at concentrations of 50,100 , 200 and $300 \mathrm{mg} / \mathrm{L} \mathrm{Cr}(\mathrm{VI})$. It was determined that Bacillus sp. M6 had a 45.9\% removal at $200 \mathrm{mg} / \mathrm{L} \mathrm{Cr}(\mathrm{VI})$ concentration, but the $\mathrm{Cr}(\mathrm{VI})$ concentration in the control did not change significantly (Li et al. 2019). It has been reported that Pseudomonas stutzeri L1 and Acinetobacter baumannii L2 strains reduce $\mathrm{Cr}(\mathrm{VI})$ by $40-97 \%$ and $84-99 \%$, respectively, at concentrations of $100-1000 \mathrm{mg} / \mathrm{L}$ (Sathishkumar et al. 2017). When we look at the studies on $\mathrm{Cr}(\mathrm{VI})$ removal with recombinant strains; as a result of the cloning of the ChrA, ChrB and ChrAB genes associated with $\mathrm{Cr}(\mathrm{VI})$ resistance of Serratia sp. to E. coli BL21, ChrA and ChrAB genes show high resistance against $\mathrm{Cr}(\mathrm{VI})$ and can confer $\mathrm{Cr}(\mathrm{VI})$ resistance ability to the strains, however, it has been observed that the protein ChrB does not have such a capacity (He et al. 2018). Pei et al. (2020) determined the most effective genes in $\mathrm{Cr}(\mathrm{VI})$ removal from waters containing 200-600 $\mu \mathrm{M} \mathrm{Cr}(\mathrm{VI})$ as $\mathrm{E}$ mcr and $\mathrm{E}-\mathrm{gsr}$ (at least $50 \% \mathrm{Cr}(\mathrm{VI})$ removal efficiency) that they cloned in to E. coli. Wang et al. (2021) expressed a $\mathrm{Cr}$ (III) adsorption protein (MerP) on the cell surface of E. coli and then combined it with a magnetic pellet system to facilitate 
$\mathrm{Cr}$ (III) adsorption. They determined that the obtained E. coli M-BL21 strain absorbed $2.38 \mathrm{mmol} / \mathrm{g} \mathrm{Cr}$ (III). These studies support our findings that more $\mathrm{Cr}$ is removed from aqueous solutions by recombinant strains than by wild strains. However, the $\mathrm{Cr}$ removal efficiency varies according to the bacterial strain used, the characteristics of the cloned gene, the $\mathrm{Cr}$ application time, the initial $\mathrm{Cr}$ concentration, and the environmental conditions ( $\mathrm{pH}$, temperature, etc.) of the medium (Fernández et al. 2018).

As the $\mathrm{Cr}(\mathrm{VI})$ concentration of the MT2A cell increases, the decrease in its growth tolerance indicates that $\mathrm{Cr}(\mathrm{VI})$ has a toxic effect on the cells at high doses. Already, the $\mathrm{Cr}(\mathrm{VI})$ bioremoval and bioreducing capacity of the MT2A strain decreased as the applied concentration increased. Similar to our findings, the cells were inhibited due to the increase in $\mathrm{Cr}(\mathrm{VI})$ toxicity on Ochrobactrum sp. (He et al. 2009), B. anthracis (Xu et al. 2015), and Microbacterium paraoxydans (Mishra et al. 2021) strains due to the increase in $\mathrm{Cr}(\mathrm{VI})$ concentration.

Changes in the morphology of cells exposed to $\mathrm{Cr}(\mathrm{VI})$ in SEM images and the Cr peak in the EDX spectra may indicate accumulation of $\mathrm{Cr}(\mathrm{III})$ on the cell surface or interior as a strategy for cells to protect themselves against $\mathrm{Cr}(\mathrm{VI})$ toxicity. Based on this information, we think that the $\mathrm{Cr}$ form accumulated in the cells in our study may be $\mathrm{Cr}$ (III). Similar to our findings, Das et al. (2021) suggested that the Cr particles adsorbed or precipitated on the outer surface of the cells from the EDX peaks obtained from the bacterial cells to which $\mathrm{Cr}(\mathrm{VI})$ was applied may be the reduced form of $\mathrm{Cr}(\mathrm{III})$. On the other hand, Zhu et al. (2008) reported that the EDX peaks of the bacterial cells to which they applied $\mathrm{Cr}(\mathrm{VI})$ may be due to $\mathrm{Cr}(\mathrm{OH})_{3}$ binding to the cell surface. Karthik et al. (2017) reported that $\mathrm{Cr}(\mathrm{VI})$ treated cells showed coarse and cluster-like morphology that increased with increasing $\mathrm{Cr}(\mathrm{VI})$ concentrations and they suggested that cluster formations of the cells might have caused to protect bacterial cells from exposure to chemical stress induced by $\mathrm{Cr}$. A similar observation was reported by Garg et al. (2013) who noted differences in SEM morphology of unexposed (control) and exposed $P$. putida cells to $500 \mathrm{mg} / \mathrm{L} \mathrm{Cr}(\mathrm{VI})$. In another study, after treatment with $100 \mathrm{mg} / \mathrm{L} \mathrm{Cr}(\mathrm{VI})$, Rhodobacter sphaeroides SC01 bacterial cells were observed to become irregular and wrinkled and cell debris appeared (Su et al. 2021). The black dots in the cell we detected in STEM images may reflect the accumulated $\mathrm{Cr}$ (III) in the cell. Similar to our comment, Pei et al. (2020) suggested that the black dot clusters seen inside the cells in the TEM images of recombinant $E$. coli with cloned E-mcr gene to which they applied $\mathrm{Cr}(\mathrm{VI})$ could be $\mathrm{Cr}(\mathrm{III})$. Similarly, it has been reported by different researchers (Karthik et al. 2017; Liu et al. 2019; Sturm et al. 2018; Su et al. 2021; Zeng et al. 2019) that these black dots observed inside the cell as a result of the application of $\mathrm{Cr}(\mathrm{VI})$ to various bacterial cells may be $\mathrm{Cr}(\mathrm{III})$.

FTIR analysis results showed that $-\mathrm{OH}$, methyl, sulfate groups of MT2A cells were effective in $\mathrm{Cr}(\mathrm{VI})$ binding. In FTIR spectra, functional groups such as amine, hydroxyl and carboxyl in the cell wall ensure the absorption of heavy metals (Pradhan et al. 2019). Cells can withstand harsh conditions by modifying their functional groups in the cell wall while adsorbed heavy metals (Zakaria et al. 2007). Karthik et al. (2017), determined that the functional groups differed according to the $\mathrm{Cr}(\mathrm{VI})$ concentration in the FTIR results of the cells to which they applied different concentrations of $\mathrm{Cr}(\mathrm{VI})$. When FTIR analysis results of Cellulosimicrobium funkei AR8 cell applied $\mathrm{Cr}(\mathrm{VI})$ were examined, it was found that alkanes, amide and amine functional groups were effective in $\mathrm{Cr}(\mathrm{VI})$ absorption (Karthik et al. 2017). A similar result is in the study conducted by Bharagava and Mishra (2018), it was determined that there are different functional groups such as alkene, carbonyl, nitro in the results of the FTIR analysis of the Cr applied cell.

\section{Conclusion}

Genetic engineering applications enable us to design microorganisms with desirable properties to enable overexpression of metal chelating proteins and peptides and the ability to increase metal accumulation for enhanced bioremediation (Tiquia-Arashiro 2018). In this study, $\mathrm{Cr}(\mathrm{VI})$ removal with genetically modified species was higher than that of wild type. In biosorption, metal accumulation takes place on the cell surface. Metal accumulation on the cell surface occurs in both living and dead cells. The genetically modified bacteria used in this study can accumulate $\mathrm{Cr}$ ions inside the cells in addition to surface adsorption due to the MT genes we cloned. To our best knowledge, the efficiency of human MT genes 
in $\mathrm{Cr}(\mathrm{VI})$ removal from aqueous solutions and reduction to $\mathrm{Cr}(\mathrm{III})$ was determined for the first time with this study. In addition, it was determined that MT2A removed more $\mathrm{Cr}(\mathrm{VI})$ than the MT3 gene. Thus, it has been demonstrated that both genes can be used as a tool in the removal or reduction of $\mathrm{Cr}(\mathrm{VI})$ from water, but MT2A is more effective. Many genes/proteins/enzymes have been used in the literature for $\mathrm{Cr}(\mathrm{VI})$ removal from water, but studies are continuing to discover the most effective biomaterial. When compared with the studies in the literature, it was concluded that the MT genes are the most effective gene that has been tried so far in $\mathrm{Cr}(\mathrm{VI})$ removal. With this study, we have added new information to these studies. In the light of this information, it can be decided which gene, protein or enzyme will be the most effective to be attached to a biosorbent in $\mathrm{Cr}(\mathrm{VI})$ removal applications from water.

\section{Declarations}

Acknowledgements This study was supported by Erciyes University Scientific Research Projects Coordination Unit (Project number: FDK-2019-9543).

Conflicts of interest The authors declare that they have no competing interests.

Availability of data and material Not applicable

Code availability Not applicable

\section{References}

1. Ahluwalia SS, Goyal D (2007) Microbial and plant derived biomass for removal of heavy metals from wastewater. Bioresour Technol 98:2243-2257. https://doi.org/https://doi.org/10.1016/j.biortech.2005.12.006

2. Akkoyun MB, Ozdemir S, Kilinc E, et al (2020) Resistance, removal, and bioaccumulation of Ni (II) and Co (II) and their impacts on antioxidant enzymes of Anoxybacillus mongoliensis. Comp Biochem Physiol Part C Toxicol Pharmacol 235:108790. https://doi.org/https://doi.org/10.1016/j.cbpc.2020.108790

3. Anusha P, Natarajan D (2020) Bioremediation potency of multi metal tolerant native bacteria Bacillus cereus isolated from bauxite mines, kolli hills, Tamilnadu- A lab to land approach. Biocatal Agric Biotechnol 25:101581. https://doi.org/https://doi.org/10.1016/j.bcab.2020.101581

4. Ayangbenro AS, Babalola $O O$ (2017) A New Strategy for Heavy Metal Polluted Environments: A Review of Microbial Biosorbents. Int. J. Environ. Res. Public Heal. 14

5. Bharagava RN, Mishra S (2018) Hexavalent chromium reduction potential of Cellulosimicrobium sp. isolated from common effluent treatment plant of tannery industries. Ecotoxicol Environ Saf 147:102-109.

https://doi.org/https://doi.org/10.1016/j.ecoenv.2017.08.040

6. Chang J, Deng S, Liang Y, Chen J (2019) Cr(VI) removal performance from aqueous solution by Pseudomonas sp. strain DC-B3 isolated from mine soil: characterization of both $\mathrm{Cr}(\mathrm{VI})$ bioreduction and total Cr biosorption processes. Environ Sci Pollut Res 26:28135-28145. https://doi.org/10.1007/s11356-019-06017-w

7. Chen S-H, Chen L, Russell DH (2014) Metal-Induced Conformational Changes of Human Metallothionein-2A: A Combined Theoretical and Experimental Study of Metal-Free and Partially Metalated Intermediates. J Am Chem Soc 136:9499-9508. https://doi.org/10.1021/ja5047878

8. Das S, Chandra Behera B, Mohapatra RK, et al (2021) Reduction of hexavalent chromium by Exiguobacterium mexicanum isolated from chromite mines soil. Chemosphere 282:131135. https://doi.org/https://doi.org/10.1016/j.chemosphere.2021.131135

9. Deng X, Jia P (2011) Construction and characterization of a photosynthetic bacterium genetically engineered for $\mathrm{Hg} 2+$ uptake. Bioresour Technol 102:3083-3088. https://doi.org/https://doi.org/10.1016/j.biortech.2010.10.051 
10. Dhal B, Thatoi HN, Das NN, Pandey BD (2013) Chemical and microbial remediation of hexavalent chromium from contaminated soil and mining/metallurgical solid waste: A review. J Hazard Mater 250-251:272-291.

https://doi.org/https://doi.org/10.1016/j.jhazmat.2013.01.048

11. Fernández PM, Fariña JI, Figueroa LIC (2010) The Significance of Inoculum Standardization and Cell Density on the $\mathrm{Cr}(\mathrm{VI})$ Removal by Environmental Yeast Isolates. Water, Air, Soil Pollut 212:275-279. https://doi.org/10.1007/s11270010-0341-0

12. Fernández PM, Viñarta SC, Bernal AR, et al (2018) Bioremediation strategies for chromium removal: Current research, scale-up approach and future perspectives. Chemosphere 208:139-148.

https://doi.org/https://doi.org/10.1016/j.chemosphere.2018.05.166

13. Garg SK, Tripathi M, Singh SK, Singh A (2013) Pentachlorophenol dechlorination and simultaneous Cr6+ reduction by Pseudomonas putida SKG-1 MTCC (10510): characterization of PCP dechlorination products, bacterial structure, and functional groups. Environ Sci Pollut Res 20:2288-2304. https://doi.org/10.1007/s11356-012-1101-z

14. Geva P, Kahta R, Nakonechny F, et al (2016) Increased copper bioremediation ability of new transgenic and adapted Saccharomyces cerevisiae strains. Environ Sci Pollut Res 23:19613-19625. https://doi.org/10.1007/s11356-0167157-4

15. Gupta S, Singh D (2017) Role of Genetically Modified Microorganisms in Heavy Metal Bioremediation. In: Advances in Environmental Biotechnology. pp 197-214

16. He Y, Dong L, Zhou S, et al (2018) Chromium resistance characteristics of $\mathrm{Cr}(\mathrm{VI})$ resistance genes ChrA and ChrB in Serratia sp. S2. Ecotoxicol Environ Saf 157:417-423. https://doi.org/https://doi.org/10.1016/j.ecoenv.2018.03.079

17. He Z, Gao F, Sha T, et al (2009) Isolation and characterization of a $\mathrm{Cr}(\mathrm{VI})$-reduction Ochrobactrum sp. strain CSCr-3 from chromium landfill. J Hazard Mater 163:869-873. https://doi.org/https://doi.org/10.1016/j.jhazmat.2008.07.041

18. Hussain S, Slikker Jr. W, Ali SF (1996) Role of metallothionein and other antioxidants in scavenging superoxide radicals and their possible role in neuroprotection. Neurochem Int 29:145-152. https://doi.org/10.1016/01970186(95)00114-x

19. Ike A, Sriprang R, Ono H, et al (2007) Bioremediation of cadmium contaminated soil using symbiosis between leguminous plant and recombinant rhizobia with the MTL4 and the PCS genes. Chemosphere 66:1670-1676. https://doi.org/https://doi.org/10.1016/j.chemosphere.2006.07.058

20. Jobby R, Jha P, Yadav AK, Desai N (2018) Biosorption and biotransformation of hexavalent chromium [Cr(VI)]: A comprehensive review. Chemosphere 207:255-266.

https://doi.org/https://doi.org/10.1016/j.chemosphere.2018.05.050

21. Karthik C, Barathi S, Pugazhendhi A, et al (2017) Evaluation of $\mathrm{Cr}(\mathrm{VI})$ reduction mechanism and removal by Cellulosimicrobium funkei strain AR8, a novel haloalkaliphilic bacterium. J Hazard Mater 333:42-53. https://doi.org/https://doi.org/10.1016/j.jhazmat.2017.03.037

22. Kathiravan MN, Karthick R, Muthukumar K (2011) Ex situ bioremediation of $\mathrm{Cr}(\mathrm{VI})$ contaminated soil by Bacillus sp.: Batch and continuous studies. Chem Eng J 169:107-115. https://doi.org/https://doi.org/10.1016/j.cej.2011.02.060

23. Kim S-K, Lee B-S, Wilson DB, Kim E-K (2005) Selective cadmium accumulation using recombinant Escherichia coli. J Biosci Bioeng 99:109-114. https://doi.org/https://doi.org/10.1263/jbb.99.109

24. Kushwaha A, Hans N, Kumar S, Rani R (2018) A critical review on speciation, mobilization and toxicity of lead in soilmicrobe-plant system and bioremediation strategies. Ecotoxicol Environ Saf 147:1035-1045.

https://doi.org/https://doi.org/10.1016/j.ecoenv.2017.09.049

25. Li M, He Z, Hu Y, et al (2019) Both cell envelope and cytoplasm were the locations for chromium(VI) reduction by Bacillus sp. M6. Bioresour Technol 273:130-135. https://doi.org/https://doi.org/10.1016/j.biortech.2018.11.006

26. Liu X, Chu G, Du Y, et al (2019) The role of electron shuttle enhances Fe(III)-mediated reduction of Cr(VI) by Shewanella oneidensis MR-1. World J Microbiol Biotechnol 35:64. https://doi.org/10.1007/s11274-019-2634-9

Page 9/15 
27. Long B, Ye B, Liu Q, et al (2018) Characterization of Penicillium oxalicum SL2 isolated from indoor air and its application to the removal of hexavalent chromium. PLoS One 13:e0191484-e0191484.

https://doi.org/10.1371/journal.pone.0191484

28. Lu Z, T. O, X. Z. Z, W. W., \& Lu F (2013) Isolation of Cr(VI) Resistant Bacteria and Exploration of Cr(VI) Removal Mechanism of Strain N-9. Appl Mech Mater 295-298:74-77

29. Ma WL, Li XF, Wang Q, et al (2019) Tandem oligomeric expression of metallothionein enhance heavy metal tolerance and bioaccumulation in Escherichia coli. Ecotoxicol Environ Saf 181:301-307.

https://doi.org/10.1016/j.ecoenv.2019.06.022

30. Ma Y, Lin J, Zhang C, et al (2011) Cd(II) and As(III) bioaccumulation by recombinant Escherichia coli expressing oligomeric human metallothioneins. J Hazard Mater 185:1605-1608.

https://doi.org/https://doi.org/10.1016/j.jhazmat.2010.10.051

31. Martone N, Rahman GMM, Pamuku M, Kingston HMS (2013) Determination of Chromium Species in Dietary Supplements Using Speciated Isotope Dilution Mass Spectrometry with Mass Balance. J Agric Food Chem 61:99669976. https://doi.org/10.1021/jf403067c

32. Miles AT, Hawksworth GM, Beattie JH, Rodilla V (2000) Induction, Regulation, Degradation, and Biological Significance of Mammalian Metallothioneins. Crit Rev Biochem Mol Biol 35:35-70. https://doi.org/10.1080/10409230091169168

33. Mishra S, Chen S, Saratale GD, et al (2021) Reduction of hexavalent chromium by Microbacterium paraoxydans isolated from tannery wastewater and characterization of its reduced products. J Water Process Eng 39:101748. https://doi.org/https://doi.org/10.1016/j.jwpe.2020.101748

34. Pan X, Liu Z, Chen Z, et al (2014) Investigation of $\mathrm{Cr}(\mathrm{VI})$ reduction and $\mathrm{Cr}(\mathrm{III})$ immobilization mechanism by planktonic cells and biofilms of Bacillus subtilis ATCC-6633. Water Res 55:21-29.

https://doi.org/https://doi.org/10.1016/j.watres.2014.01.066

35. Pei Y, Tao C, Ling Z, et al (2020) Exploring novel $\mathrm{Cr}(\mathrm{VI})$ remediation genes for $\mathrm{Cr}(\mathrm{VI})$-contaminated industrial wastewater treatment by comparative metatranscriptomics and metagenomics. Sci Total Environ 742:140435. https://doi.org/https://doi.org/10.1016/j.scitotenv.2020.140435

36. Pinto E, Sigaud-kutner TCS, Leitão MAS, et al (2003) HEAVY METAL-INDUCED OXIDATIVE STRESS IN ALGAE1. J Phycol 39:1008-1018. https://doi.org/https://doi.org/10.1111/j.0022-3646.2003.02-193.x

37. Pradhan D, Sukla LB, Mishra BB, Devi N (2019) Biosorption for removal of hexavalent chromium using microalgae Scenedesmus sp. J Clean Prod 209:617-629. https://doi.org/https://doi.org/10.1016/j.jclepro.2018.10.288

38. Pradhan D, Sukla LB, Sawyer M, Rahman PKSM (2017) Recent bioreduction of hexavalent chromium in wastewater treatment: A review. J Ind Eng Chem 55:1-20. https://doi.org/https://doi.org/10.1016/j.jiec.2017.06.040

39. Sathishkumar K, Murugan K, Benelli G, et al (2017) Bioreduction of hexavalent chromium by Pseudomonas stutzeri L1 and Acinetobacter baumannii L2. Ann Microbiol 67:91-98. https://doi.org/10.1007/s13213-016-1240-4

40. Shamim S, Rehman A, Qazi MH (2014) Cadmium-Resistance Mechanism in the Bacteria Cupriavidus metallidurans CH34 and Pseudomonas putida mt2. Arch Environ Contam Toxicol 67:149-157. https://doi.org/10.1007/s00244-0140009-7

41. Starska K, Bryś M, Forma E, et al (2015) The effect of metallothionein 2A core promoter region single-nucleotide polymorphism on accumulation of toxic metals in sinonasal inverted papilloma tissues. Toxicol Appl Pharmacol 285:187-197. https://doi.org/10.1016/j.taap.2015.04.008

42. Sturm G, Brunner S, Suvorova E, et al (2018) Chromate Resistance Mechanisms in Leucobacter chromiiresistens. Appl Environ Microbiol 84:e02208-18. https://doi.org/10.1128/AEM.02208-18

43. Su Y-Q, Yuan S, Guo Y-C, et al (2021) Highly efficient and sustainable removal of $\mathrm{Cr}(\mathrm{VI})$ in aqueous solutions by photosynthetic bacteria supplemented with phosphor salts. Chemosphere 283:131031.

https://doi.org/https://doi.org/10.1016/j.chemosphere.2021.131031

Page $10 / 15$ 
44. Tiquia-Arashiro SM (2018) Lead absorption mechanisms in bacteria as strategies for lead bioremediation. Appl Microbiol Biotechnol 102:5437-5444. https://doi.org/10.1007/s00253-018-8969-6

45. Toriumi S, Saito T, Hosokawa T, et al (2005) Metal Binding Ability of Metallothionein-3 Expressed in Escherichia coli. Basic Clin Pharmacol Toxicol 96:295-301. https://doi.org/10.1111/j.1742-7843.2005.pto960404.x

46. Uçkun AA, Uçkun M, Akkurt Ş (2021) Bioremoval of arsenic from aqueous solutions with metallothionein gene cloned recombinant Escherichia coli strains. J Eng Sci Adıyaman Univ 8:244-252

47. USEPA (2014) Toxic and Priority Pollutants Under the Clean Water Act Priority Pollutant List

48. Wang J, Zhao S, Ling Z, et al (2021) Enhanced removal of trivalent chromium from leather wastewater using engineered bacteria immobilized on magnetic pellets. Sci Total Environ 775:145647.

https://doi.org/https://doi.org/10.1016/j.scitotenv.2021.145647

49. WHO (2017) Guidelines for drinking-water quality World Health Organization

50. Wu M, Li Y, Li J, et al (2019) Bioreduction of hexavalent chromium using a novel strain CRB-7 immobilized on multiple materials. J Hazard Mater 368:412-420. https://doi.org/https://doi.org/10.1016/j.jhazmat.2019.01.059

51. Xu W-H, Jian H, Liu Y-G, et al (2015) Bioreduction of Chromate by an Isolated Bacillus anthracis Cr-4 with Soluble Cr(III) Product. Water, Air, Soil Pollut 226:82. https://doi.org/10.1007/s11270-015-2356-Z

52. Yang T, Chen M-L, Wang J-H (2015) Genetic and chemical modification of cells for selective separation and analysis of heavy metals of biological or environmental significance. TrAC Trends Anal Chem 66:90-102.

https://doi.org/https://doi.org/10.1016/j.trac.2014.11.016

53. Zakaria ZA, Zakaria Z, Surif S, Ahmad WA (2007) Hexavalent chromium reduction by Acinetobacter haemolyticus isolated from heavy-metal contaminated wastewater. J Hazard Mater 146:30-38.

https://doi.org/https://doi.org/10.1016/j.jhazmat.2006.11.052

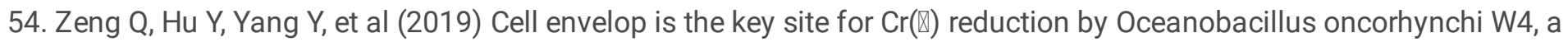
newly isolated $\mathrm{Cr}(\mathbb{Z})$ reducing bacterium. J Hazard Mater 368:149-155.

https://doi.org/https://doi.org/10.1016/j.jhazmat.2019.01.031

55. Zhu W, Chai L, Ma Z, et al (2008) Anaerobic reduction of hexavalent chromium by bacterial cells of Achromobacter sp. Strain Ch1. Microbiol Res 163:616-623. https://doi.org/https://doi.org/10.1016/j.micres.2006.09.008

\section{Figures}




\section{Cr removal rates (\%)}

120

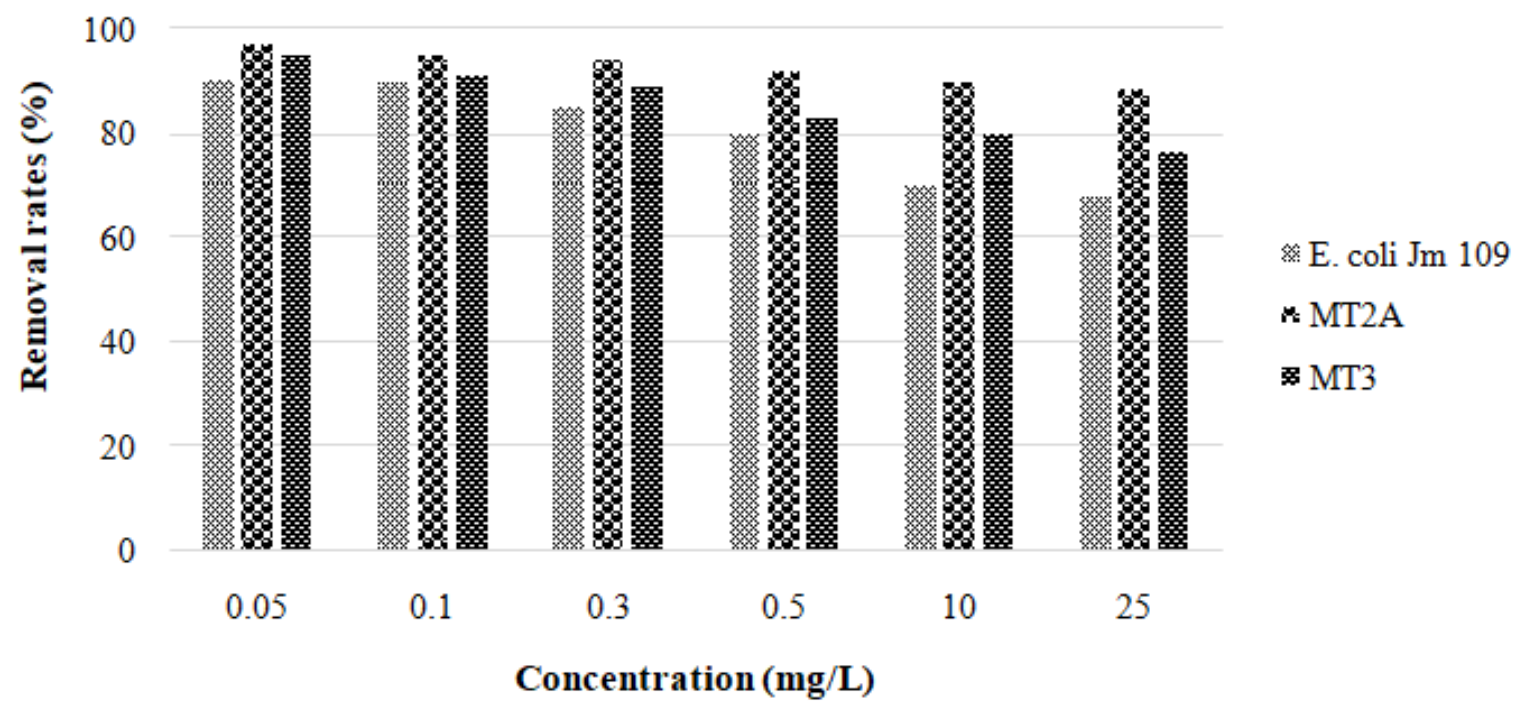

Figure 1

$\mathrm{Cr}$ removal rates of bacterial cells from the medium

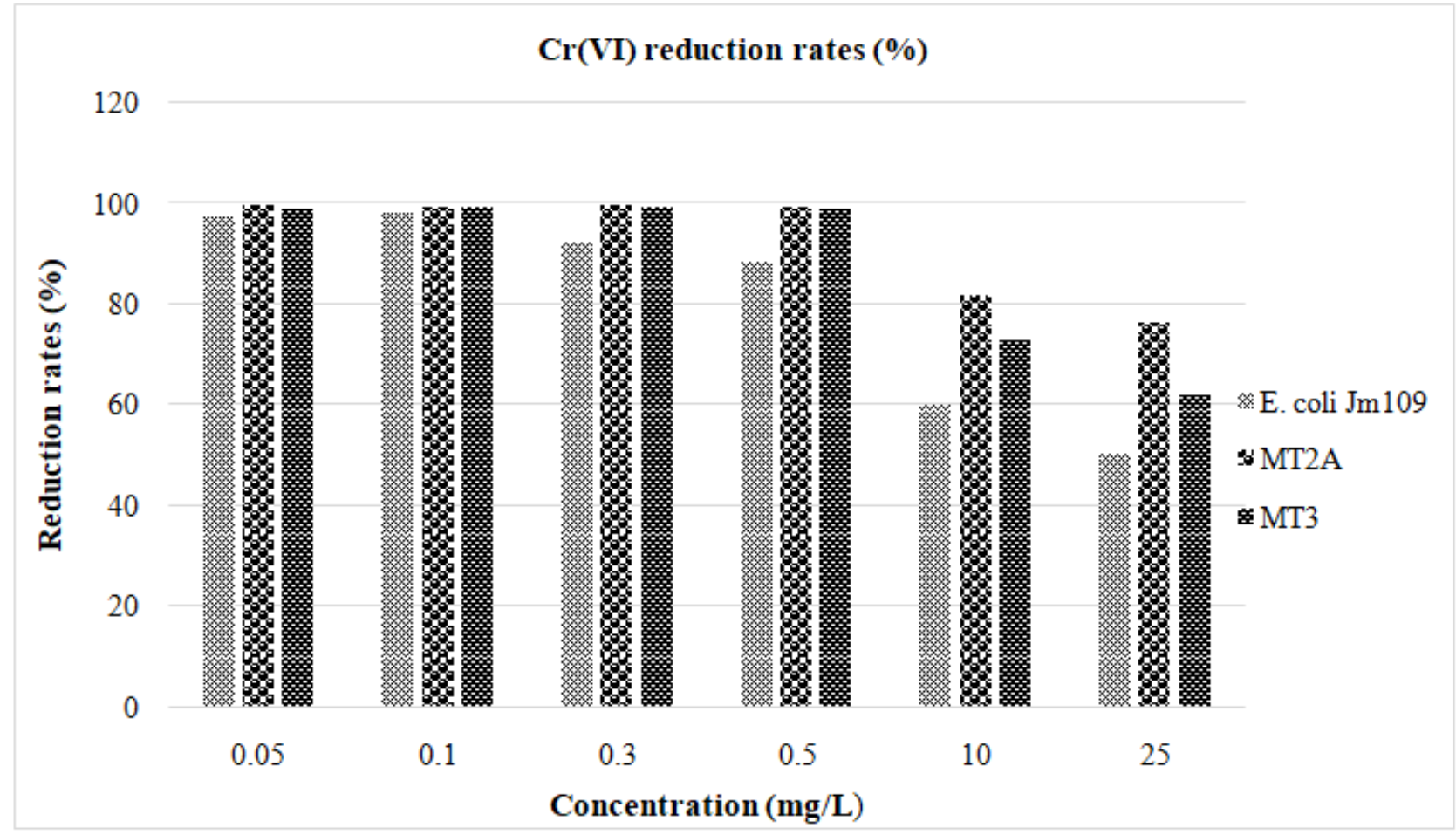

Figure 2

$\mathrm{Cr}(\mathrm{VI})$ reduction rates from media 


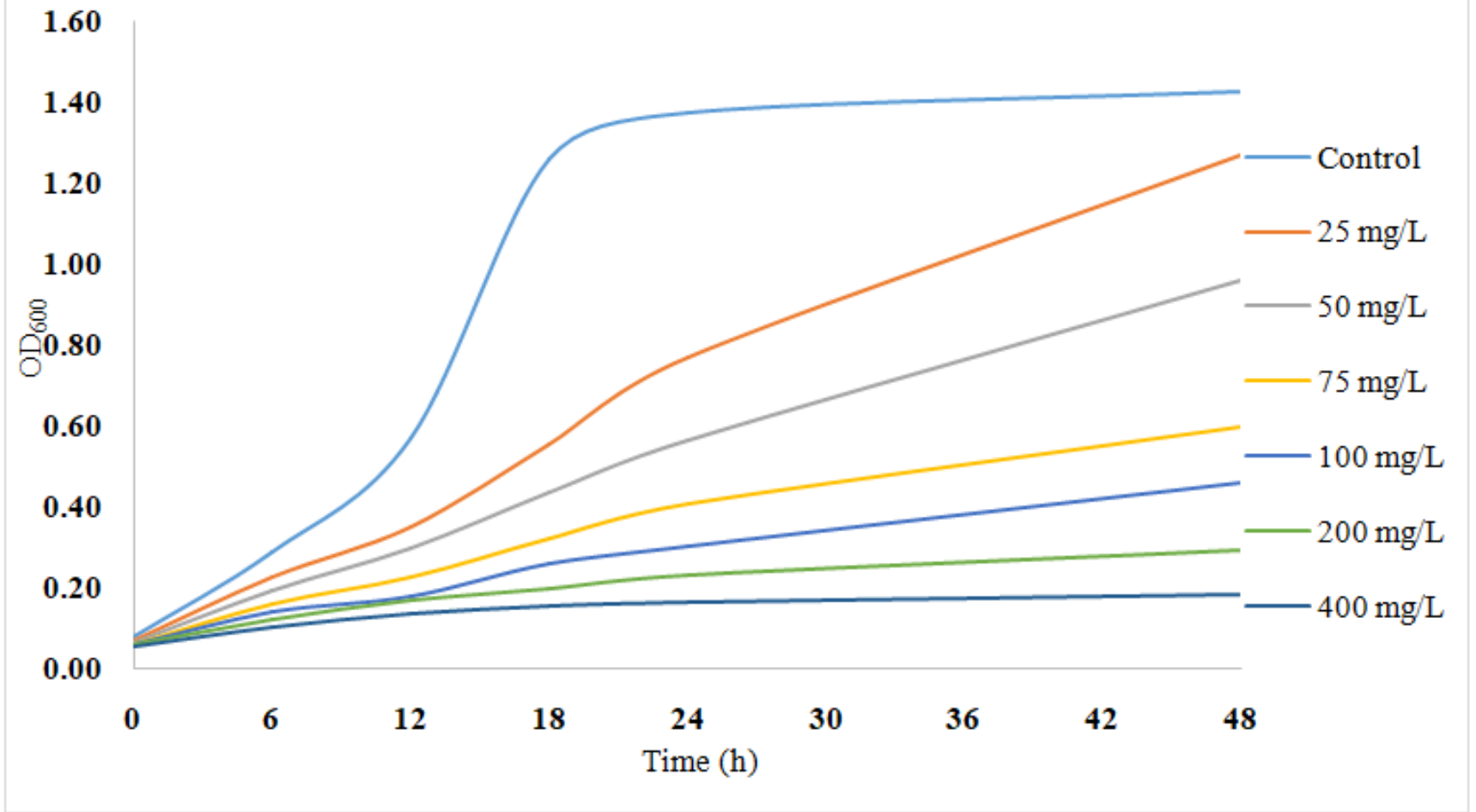

Figure 3

Growth curve of MT2A strain exposed to different $\mathrm{Cr}(\mathrm{VI})$ concentration 

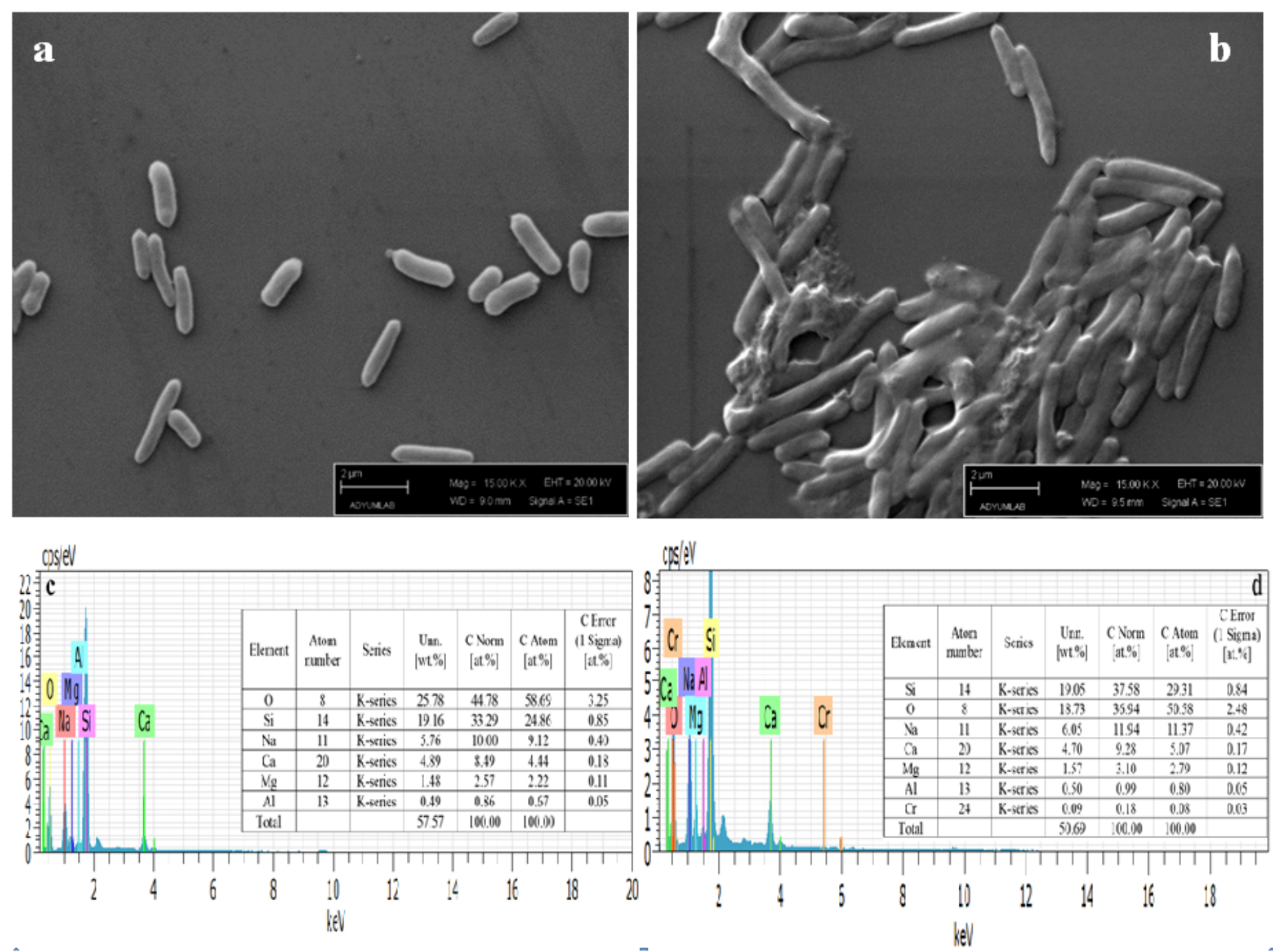

\section{Figure 4}

SEM imagesand EDX spectrums of bacterial cells a SEM image of untreated $\mathrm{Cr}(\mathrm{VI})$ cells b SEM image of $25 \mathrm{mg} / \mathrm{L} \mathrm{Cr}(\mathrm{VI})$ treated cells c EDX spectrum of untreated $\mathrm{Cr}(\mathrm{VI})$ cells d EDX spectrum of $25 \mathrm{mg} / \mathrm{L} \mathrm{Cr}(\mathrm{VI})$ treated cells

\section{$\mathbf{a}$}
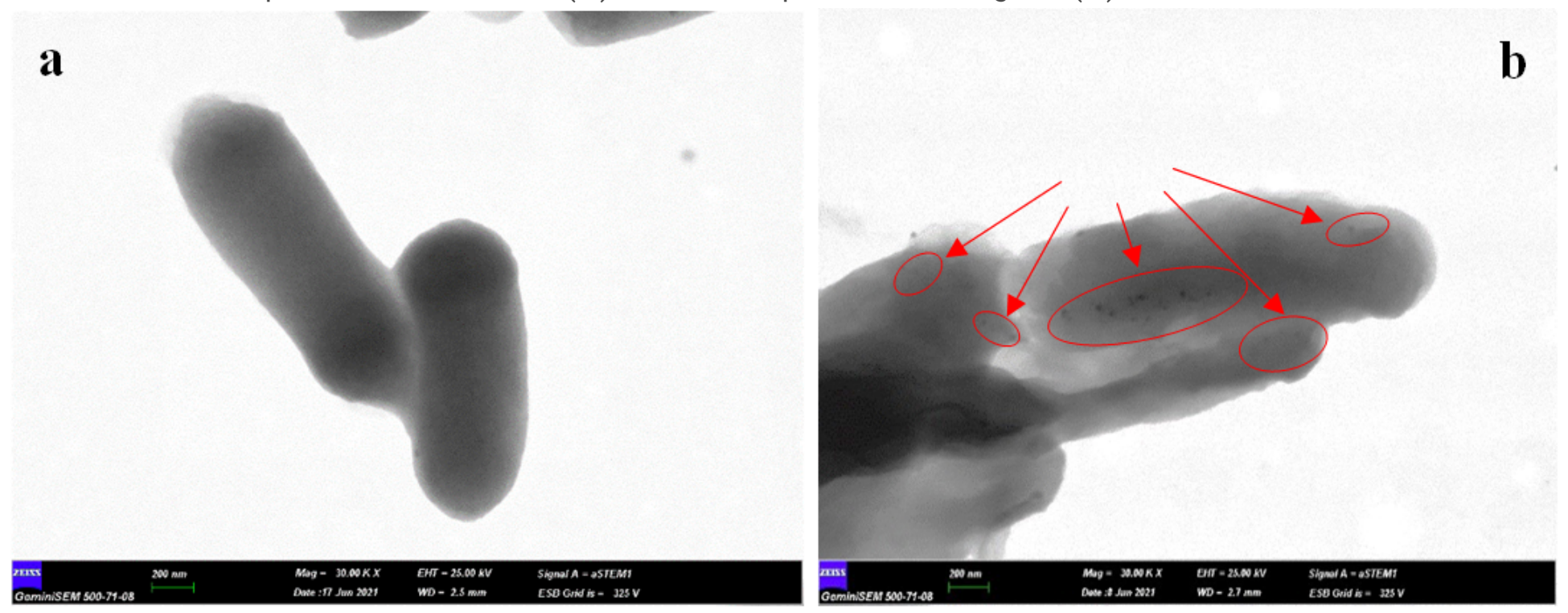
Figure 5

STEM images of bacterial cells a untreated $\mathrm{Cr}(\mathrm{VI})$ cells b $25 \mathrm{mg} / \mathrm{L} \mathrm{Cr}(\mathrm{VI})$ treated cells

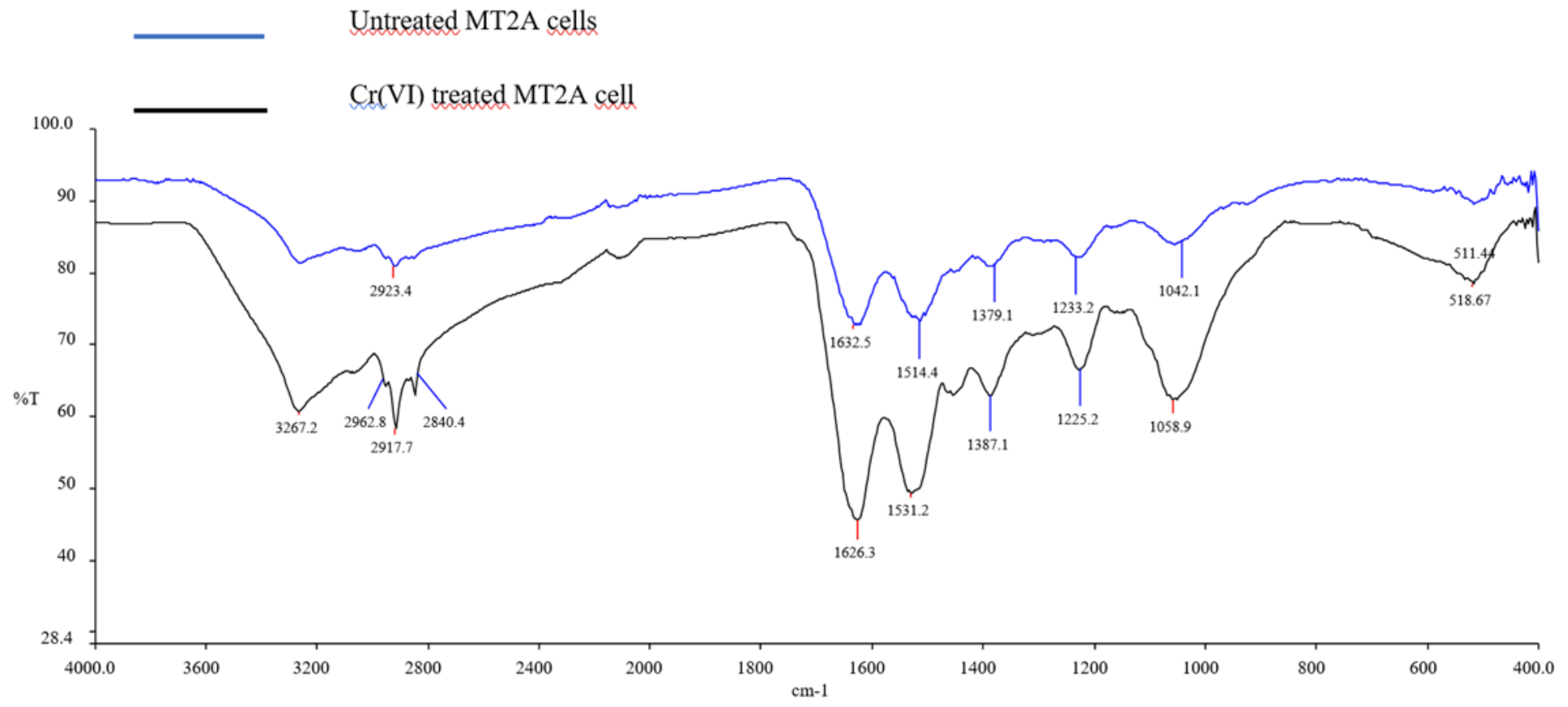

Figure 6

FTIR spectra of control (untreated $\mathrm{Cr}(\mathrm{VI})$ ) and $25 \mathrm{mg} / \mathrm{L} \mathrm{Cr}(\mathrm{VI})$ treated MT2A cell

\section{Supplementary Files}

This is a list of supplementary files associated with this preprint. Click to download.

- GRAPHICALABSTRACT.pdf 